\title{
Intervenção ergonômica no trabalho em olarias artesanais: o caso do município de Rosário (MA).
}

\author{
Ana Tássia Silva Franco ${ }^{1}$ \\ Raimundo Lopes Diniz ${ }^{2}$
}

Resumo:

A região de Rosário é considerada um dos principais polos cerâmicos maranhenses caracteriza-se por ser uma localidade onde há abundância, tanto da matéria-prima (argila), quanto de produção de artefatos tornando-se um forte setor produtivo na região (CARACAS et al., 2012). As olarias são os locais onde são fabricadas as peças de cerâmica que mesmo diante dos avanços tecnológicos e das mudanças nos hábitos da sociedade resistem utilizando técnicas rudimentares de fabricação, estando atualmente limitados a produção de filtros, vasos, objetos decorativos entre outros itens, para o mercado local e regional. Para Bentes et. al (2012) esse tipo de atividade possui escassez de equipamentos e gestão sendo, portanto, ambientes de poucos recursos e que podem desencadear sérios problemas à saúde e a segurança desse trabalhador. A ergonomia aplicada ao local de trabalho tem como função permitir que os artesãos tenham ambientes mais seguros e confortáveis, evitando possíveis afastamentos e promovendo melhor desempenho das atividades produtivas (FIGUEIREDO, 2015). De caráter interdisciplinar, a ergonomia agrega-se a várias disciplinas que sustentam a sua base científica e tecnológica. Carriel e Paschoarelli (2009) acrescentam ainda que o design é uma dessas disciplinas que trazem de forma correlata um elo para que os objetivos da ergonomia sejam amplamente alcançados e estabelecidos. Sendo assim, a ergonomia lida com um largo escopo de problemas relevantes ao design e avaliação de sistemas de trabalho, produtos de consumo e ambientes de trabalho nos quais as interações humano-máquina afetam o desempenho humano e a usabilidade dos produtos. Diante do contexto observado surgiu o questionamento sobre como uma intervenção ergonômica poderia auxiliar à identificação de fatores de risco no trabalho de artesãos ceramistas. Desta forma, o objetivo da pesquisa é compreender o trabalho das olarias de Rosário (MA) através de uma intervenção ergonômica, a fim de detectar possíveis problemas ergonômicos relacionados a essas atividades criativas. Pretende-se descrever as condições de trabalho no âmbito geral até a geração de uma hierarquia quanto aos constrangimentos ergonômicos encontrados e finalmente, o aprofundamento relacionado aos fatores musculoesqueléticos ligados às posturas ocupacionais. Assim pode-se categorizar conforme Santos (2018) a pesquisa como descritiva e explicativa sob abordagem quali-quantitativa, sendo, portanto, um estudo de caso pois possui ênfase fenomenológica e holística do fenômeno (Trabalho das olarias). Será utilizado o método de Intervenção ergonomizadora de Morais e Mont'Alvão (2003), até a fase da diagnose ergonômica. Serão utilizadas técnicas de cunho descritivo, como a aplicação de entrevistas estruturadas,

\footnotetext{
${ }^{1}$ http://lattes.cnpq.br/2963012163900084

2 http://lattes.cnpq.br/9755992709224022
} 


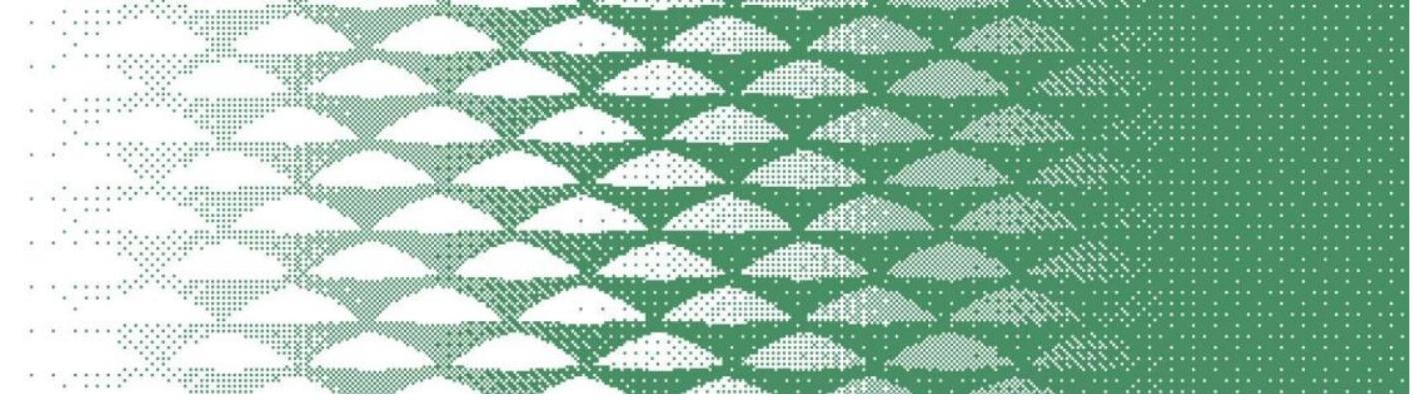

questionário fechado para a problematização quanto ao sistema-alvo estudado ("artesãos ceramistas") e a técnica GUT (Gravidade, Urgência e Tendência) para hierarquizar os constrangimentos encontrados. Em seguida serão usadas técnicas de avaliação da postura ocupacional como diagrama de CORLETT (1976) e REBA (2000), para a diagnose ergonômica, partindo-se da hipótese de que "há a presença de desconforto/dor entre os artesãos ceramistas". Com a pesquisa espera-se contribuir com propostas de intervenção que visem a prevenção ou diminuição de riscos à saúde de artesãos ceramistas que trabalham especificamente em olarias, propiciando também meios para discussões mais abrangentes no que se refere às melhorias da qualidade de vida dos envolvidos neste processo.

Palavras-chave: Intervenção ergonômica; olarias; trabalho; constrangimentos ergonômicos.

\section{Referências:}

BENTES, F. M.; FERREIRA, S. S.; LAMERA, D. L.; MANTOVANI, O. C.; POSSEBON, J. Cerâmica vermelha: Processo produtivo e áreas de vivência requerem melhorias. Revista Proteção Ed. 244, abril 2012. Disponível em: http://www.protecao.com.br/edicoes/4/2012/A5ja. Acesso em: 14 de setembro de 2021.

CARACAS, L. B.; SANTOS, D; GUARÁ, T; JÚNIOR J. M. G.; ELÍ J. S. Design e produção artesanal em cerâmica: um estudo de caso em Rosário-MA. 10 P\&D Design, São Luís- MA, 2012.

CARRIEL, Ivan Ricardo Rodrigues; PASCHOARELLI, Luís Carlos. Design e ergonomia: aspectos tecnológicos / Luís Carlos Paschoarelli, Marizilda dos Santos Menezes (org.). - São Paulo: Cultura Acadêmica, 2009.Disponível em: https://static.scielo.org/scielobooks/yjxnr/pdf/paschoarelli9788579830013.pdf. Acesso em: 25 de agosto de 2021.

CORLETT, E. N.; BISHOP, R.P. A technique for assessing postural discomfort. Ergonomics, $n$. 29, 1976. p. 281-283.

FIGUEIREDO, Monica Parisi. Análise Ergonômica do Trabalho - Fábrica de cerâmica. Curitiba 2015. Disponível em: https://acervodigital.ufpr.br/bitstream/handle/1884/43328/R\%20-\%20E\%20\%20MONICA\%20PARISI\%20FIGUEIREDO.pdf?sequence=18isAllowed=y. Acesso em: 24 de agosto de 2021.

HIGNETT, S.; MCATAMNEY, L. Rapid Entire Body Assessment (REBA). Applied ergonomics, n. 31, 2000. p. 201-105.

MORAES, Ana, MONT'ALVÃO, Cláudia. Ergonomia: conceitos e aplicações. Rio de Janeiro: IUsEr, 2003.

SANTOS, Aguinaldo dos. Seleção do método de pesquisa: guia para pós-graduando em design e áreas afins. Curitiba, PR: Insight, 2018. 


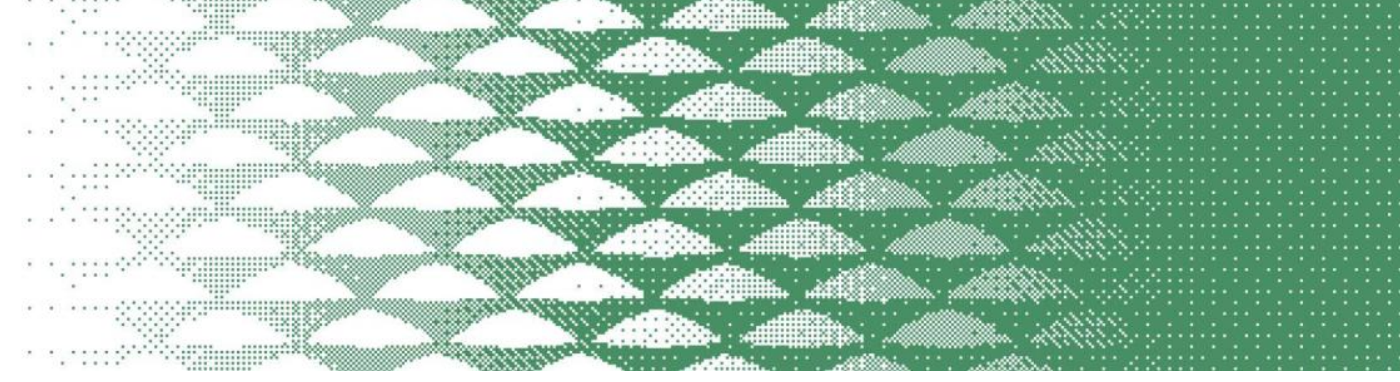

Espaço reservado para organização do congresso. 